\title{
Parental Incarceration: Recent Trends and Implications for Child Welfare
}

\author{
Elizabeth I. Johnson \\ University of Michigan \\ Jane Waldfogel \\ Columbia University
}

\begin{abstract}
Using national survey data, we analyze 11-year trends in parental incarceration. Results indicate that children with incarcerated parents have become an increasingly large share of the foster care population since the mid-1980s and a notable share of U.S. children living with grandparent caregivers. Findings underscore the need to develop and implement specific child welfare and criminal justice policies for serving these families.
\end{abstract}

Although advocates, child welfare workers, and, more recently, academics have become concerned about the challenges posed for children, families, and the child welfare system by parental incarceration, relatively little is known about the magnitude and growth of parental incarceration. Estimates of the proportion of inmates that are parents vary widely (Johnston 1995). Part of this disparity is definitional; some studies count parents with children of any age, while others include only parents with minor children (Schafer and Dellinger 1999). Perhaps a larger share of the problem, however, is methodological. Studies rely on various data sources, including national surveys, samples from different regions of the country, and personal interviews with small samples of inmates

Social Service Review (September 2002).

(C) 2002 by The University of Chicago. All rights reserved.

0037-7961/2002/7603-0005\$10.00 
(usually women). It has been difficult to use these disparate data to identify national trends over time.

\section{Background}

A considerable portion of the research on incarcerated parents focuses on their children, especially children whose mothers are incarcerated. These studies suggest that parental incarceration can negatively affect emotional, behavioral, and psychological development (Stanton 1980; Baunach 1985; Bloom and Steinhart 1993). For instance, problems such as aggressive behavior and withdrawal (Baunach 1985); criminal involvement (Johnston 1991, 1992); and depression, difficulty sleeping, and concentration problems (Kampfner 1995) have been reported among children whose parents are incarcerated.

But research also indicates that children of incarcerated parents may be at risk long before their parents are incarcerated. The U.S. Department of Justice reports that nearly 60 percent of women in state prisons used drugs in the month prior to their offense and that approximately 50 percent described themselves as regular substance users (Greenfeld and Snell 1999). Moreover, 65 percent of women and 77 percent of men in state prisons have a history of prior convictions (Greenfeld and Snell 1999). Histories of sexual and physical abuse, mental illness, and parental incarceration (U.S. Department of Justice, Bureau of Justice Statistics 1993) and low socioeconomic status (Baunach 1985; Bloom and Steinhart 1993; Kampfner 1995) are also common among inmates. Overall, research indicates the presence of multiple risk factors in the lives of incarcerated parents and their children.

There has also been some attention to where children are placed when a parent goes to prison. There is evidence that child placements depend on the gender of the parent, with children of incarcerated mothers more likely to be displaced from the home than children of incarcerated fathers (Johnston 1991; Mumola 2000). While living with a grandparent is the most common arrangement for children of incarcerated mothers (Mumola 2000), a larger share of these children end up in the child welfare system than children of incarcerated fathers (Johnston 1991; Bloom and Steinhart 1993; Mumola 2000). Estimates of the number of children with incarcerated parents who end up in the foster care system vary. For children with mothers in prison, these estimates range from 10 percent (Johnston 1993) to 14 percent (McGowan and Blumenthal 1978).

Concern about the long-term consequences of incarceration for children and families has been heightened by the fact that child welfare legislation, such as the Adoption Assistance and Child Welfare Act of 1980 (P.L. 96-272) and the Adoption and Safe Families Act of 1997 (ASFA; P.L. 105-89), has created tensions between what parents are 
expected to do and what incarcerated parents are capable of doing from the confines of prison (Beckerman 1989, 1991, 1998; Genty 1995, 1998). Though barriers to fulfilling legal obligations for incarcerated parents are not new, ASFA heightened these tensions by imposing a requirement that states must file a petition to terminate parental rights when a child has been in state care for 15 of the last 22 months. Given the increase in sentence lengths and amount of time served, this requirement may be particularly consequential for incarcerated parents (Genty 1998). The ASFA permits states to opt out of this requirement if the child is living with a relative, though data from the National Conference of State Legislatures suggests that not all states are exercising this right (National Conference of State Legislatures 2001).

There is also some evidence that agency-level policies and practices heighten the tensions between the demands of permanency planning and the constraints imposed by parental incarceration. In one of the first studies of the role of child welfare services in correctional facilities, Dorothy Zietz (1963) discovered a general lack of information and confusion about mothers' rights and responsibilities (among mothers and caseworkers). Brenda McGowan and Karen Blumenthal (1978) were also early contributors to this literature, providing estimates on the number of children with parents in prison, describing children's living arrangements during incarceration, and delineating the unique service needs of incarcerated parents. This work also revealed limited communication between mothers and caseworkers, particularly regarding legal issues. More recently, Adela Beckerman (1994) observes that many incarcerated mothers with children in foster care received no correspondence (49 percent) from caseworkers and were often uninformed of child custody hearings (28 percent). Two-thirds (66 percent) of mothers reported not receiving a copy of their child's case plan.

Moreover, there are often no specific child welfare policies for dealing with children of incarcerated parents. A relatively recent survey of 500 child welfare, law enforcement, and correctional officials (Smith and Elstein 1994) revealed that 80 percent of protective service agencies surveyed had no specific policies or guidelines for placing children whose mothers had been arrested. Although more than 50 percent of child welfare administrators acknowledged an increase in the number of children of incarcerated parents requiring placement, most reported a lack of formal procedures for working with this population.

A 1997 survey by the Child Welfare League of America (1998) revealed low levels of state-sponsored services and policies for incarcerated parents and their families. For example, of the 38 states that responded, only 6 percent reported specific policies pertaining to children with incarcerated parents. Only 25 states provide transportation for children to visit incarcerated parents (Child Welfare League of America 1998), even though the majority of incarcerated parents (62 percent of parents 
in state prison and 84 percent of parents in federal prison) are incarcerated more than 100 miles away from their homes (Mumola 2000).

Before considering an adequate policy and service response, it is first necessary to determine the number of parents in prison and the number of their children. Information on how parents' demographic characteristics and children's living arrangements have changed over time will also contribute to understanding the problem. This study builds on existing work by examining these issues on a national scale from 1986 to 1997 .

\section{Data and Method}

We analyze trends in parental incarceration using the 1986 and 1991 Survey of Inmates in State Correctional Facilities and the 1997 Survey of Inmates in State and Federal Correctional Facilities (U.S. Department of Justice, Bureau of Justice Statistics 1993b, 1994, 2000). The 1986 and 1991 surveys contain data on state inmates only (separate surveys collected data on federal inmates in these years); the 1997 survey contains data on both state and federal inmates. Except for estimates on the growth of parents in prison that utilize data on state and federal inmates, our substantive analyses are limited to state inmates.

Inmate surveys have been conducted by the U.S. Census Bureau every 5 years since 1974. Examining the three most recent waves should sufficiently capture the dramatic increase in rates of incarceration of parents (especially mothers), which is largely thought to be a function of the shift in national drug policy that occurred during the mid- to late 1980s (i.e., the Anti Drug Abuse Acts of 1986 and 1988 and the Sentencing Reform Act of 1984 that changed sentencing laws) concurrent with the rapid increase in use of crack cocaine.

The inmate surveys contain detailed information on inmates' criminal history, drug and alcohol use, prison activities, conditions of confinement, family background, demographic characteristics, and a number of other variables. For 1986, 1991, and 1997, personal interviews were conducted in about 270-75 correctional facilities, yielding large samples of between 13,000 and 17,000. A stratified, two-stage selection process was used, whereby prisons were selected first and inmates in sampled prisons were subsequently sampled. Second-stage response rates were high-approximately 93 percent for all 3 years. Each year contains a roughly comparable set of variables and, when weighted, is nationally representative of inmates in state prisons. Weights provided by the $\mathrm{Bu}-$ reau of Justice Statistics were used in all analyses.

Parents were selected for analysis if they had at least one child under the age of 18. For estimates of the number of children with parents in state prison, we aggregated the number of children per inmate per year. ${ }^{1}$ The proportion of children in each living arrangement was calculated 
Table 1

Number of Parents in State and Federal Prison

\begin{tabular}{lrrrr}
\hline & 1986 & 1991 & 1997 & Change from 1986 to 1997 (\%) \\
\hline Mothers & 14,997 & 28,517 & 46,679 & +210 \\
Fathers & 258,048 & 409,604 & 590,630 & +115 \\
Total & 273,045 & 438,121 & 637,309 & +133 \\
\hline
\end{tabular}

by weighting arrangements (which are reported at the level of the family rather than the child) by the parent's number of children. As noted above, most of the analyses in this article refer to children of state prisoners only. However, we do use data on federal inmates to estimate the overall magnitude of the problem. For these analyses, figures provided by the Bureau of Justice Statistics' Correction Population in the United States, 1986 and 1991 (U.S. Department of Justice 1989, 1993a) and the Incarcerated Parents and Their Children report (Mumola 2000) were used to estimate the number of parents in federal prison for 1986 and 1991; data on federal inmates for 1997 were obtained from the 1997 Survey of Inmates in State and Federal Correctional Facilities (U.S. Department of Justice, Bureau of Justice Statistics 2000).

\section{Results}

Growth in the Number of Parents in Prison

Table 1 depicts the increase in the number of parents in state and federal prison between 1986 and 1997. The number of parents in prison more than doubled during this 11-year period, from 273,045 in 1986 to 637,309 in 1997. The number of children with a parent in prison also rose dramatically, from a little over 600,000 in 1986 to more than 1.3 million in 1997 (table 2). Put differently, about 10 in every 1,000 U.S. children had a parent in state or federal prison in 1986, while nearly 20 in every 1,000 children had a parent in prison during 1997. The number of women in prison more than tripled during this period.

We turn next to analyses of state prisoners, who make up the bulk of inmates and for whom we have comparable data for 1986, 1991, and 1997. In the following sections, we use these data to analyze the characteristics of the population of parents in state prison and how those characteristics have changed over time.

\section{Demographic Changes}

On average, parents incarcerated in state prisons during 1997 had fewer children, were less likely to be married or previously married, and were 
Table 2

Number of Children with Parents in State or Federal Prison

\begin{tabular}{rrrrc}
\hline & 1986 & \multicolumn{1}{c}{1991} & 1997 & Change from 1986 to $1997(\%)$ \\
\hline State & 545,457 & 977,256 & $1,199,271$ & +120 \\
Federal & 59,951 & 84,200 & 121,977 & +103 \\
\cline { 2 - 4 } Total & 605,408 & $1,061,456$ & $1,321,248$ & +118 \\
\hline
\end{tabular}

better educated than parents incarcerated in state prisons during 1986 (table 3). Larger shares of both mothers and fathers report Hispanic ethnicity in 1991 and 1997 than in 1986. A slightly larger percentage of both mothers and fathers identified as African American in 1997 than in 1986.

Across all three points in time, more mothers than fathers report having custody of children prior to incarceration. However, fewer mothers and fathers reported living with their children in 1997 than in 1986 or 1991 (table 3): 78 percent of 1986 mothers, 71.7 percent of 1991 mothers, and only 64.3 percent of 1997 mothers lived with their children prior to incarceration. The percentage of fathers who lived with their children prior to incarceration also decreased, from 50.5 percent in 1986 to 43.8 percent in 1997.

\section{Family Background Characteristics}

The majority of parents incarcerated in state prison grew up in a twoparent home with a mother and father (table 4). The second most common childhood living arrangement was with a lone mother. The proportion of parents (both mothers and fathers) who lived primarily in foster care or in the care of agency declined from 1986 to 1997: 3.3 percent of mothers and 2.4 percent of fathers in 1986 declared foster or agency care as the primary living arrangement in 1986, while only 2.2 percent and 1.2 percent did for 1997. Similarly, the proportion of inmates who ever lived in foster care declined slightly from 1991 (16.3 percent for mothers, 14.6 percent for fathers) to 1997 (15.2 percent for mothers, 12.8 percent for fathers).$^{2}$

Parents incarcerated in state prisons during 1997 identified risk factors such as a history of physical and sexual abuse and incarceration of their own parents with greater frequency than did parents incarcerated in state prisons during 1986 and 1991 (table 4). For instance, 36.1 percent of 1986 mothers and 47.6 percent of 1997 mothers report having ever been physically abused. This increase was less pronounced for fathers: 10.4 percent of 1986 fathers and 12.8 percent of 1997 fathers report a history of physical abuse. The reported prevalence of sexual 
Table 3

Demographic Characteristics of Parents in State Prison

\begin{tabular}{|c|c|c|c|c|c|c|}
\hline & \multicolumn{2}{|c|}{$1986^{\mathrm{a}}$} & \multicolumn{2}{|c|}{$1991^{\mathrm{a}}$} & \multicolumn{2}{|c|}{$1997^{\mathrm{a}}$} \\
\hline & $\begin{array}{c}\text { Mothers } \\
n=1,967 \\
(13,382)\end{array}$ & $\begin{array}{c}\text { Fathers } \\
n=5,769 \\
(231,856)\end{array}$ & $\begin{array}{c}\text { Mothers } \\
n=1,865 \\
(25,617)\end{array}$ & $\begin{array}{c}\text { Fathers } \\
n=6,179 \\
(373,104)\end{array}$ & $\begin{array}{c}\text { Mothers } \\
n=1,889 \\
(42,963)\end{array}$ & $\begin{array}{c}\text { Fathers } \\
n=6,158 \\
(538,761)\end{array}$ \\
\hline Average number of children & 2.48 & 2.22 & 2.57 & 2.45 & 2.38 & 2.04 \\
\hline $\begin{array}{l}\text { Living with child(ren) prior to } \\
\text { incarceration }(\%)\end{array}$ & 78 & 50.5 & 71.7 & 52.8 & 64.3 & 43.8 \\
\hline Average age & 30.16 & 31.25 & 31.00 & 31.72 & 32.90 & 33.04 \\
\hline \multicolumn{7}{|l|}{ Race $(\%):$} \\
\hline \multicolumn{7}{|l|}{ Non-Hispanic: } \\
\hline White & 35.2 & 34.3 & 33.6 & 29.7 & 32.1 & 28.6 \\
\hline Black & 49.1 & 48.6 & 47.5 & 49.4 & 48.4 & 49.4 \\
\hline Asian & .7 & .9 & .8 & .5 & 1.1 & .7 \\
\hline Native American & 2.3 & 1.4 & 2.6 & 1.6 & 2.3 & 1.9 \\
\hline Hispanic & 12.7 & 14.3 & 15.2 & 18.7 & 15.8 & 19.2 \\
\hline \multicolumn{7}{|l|}{ Marital status (\%): } \\
\hline Married & 23.3 & 30.2 & 19.8 & 25.6 & 19.5 & 23.3 \\
\hline Widowed & 5.9 & 1.6 & 4.1 & 1.3 & 4.1 & 1.4 \\
\hline Divorced & 21.6 & 23.3 & 18.6 & 21.4 & 20.4 & 20.5 \\
\hline Separated & 11.8 & 8.0 & 13.5 & 8.0 & 9.8 & 7.0 \\
\hline Never married & 37.4 & 36.8 & 43.1 & 42.7 & 46.2 & 47.8 \\
\hline Completed high school/have GED (\%) & 39.4 & 43.0 & 54.0 & 58.7 & 46.6 & 52.8 \\
\hline
\end{tabular}

Source. - Authors' analyses of the Survey of Inmates in State Correctional Facilities, 1986 (U.S. Department of Justice, Bureau of Justice Statistics 1994), Survey of Inmates in State Correctional Facilities, 1991 (U.S. Department of Justice, Bureau of Justice Statistics 1993), and Survey of Inmates in State and Federal Correctional Facilities, 1997 (U.S. Department of Justice, Bureau of Justice Statistics 2000).

${ }^{a} n=$ sample size (weighted value in parentheses). 
Table 4

Family Background Characteristics $(\%)$

\begin{tabular}{|c|c|c|c|c|c|c|}
\hline & \multicolumn{2}{|c|}{$1986^{a}$} & \multicolumn{2}{|c|}{$1991^{a}$} & \multicolumn{2}{|c|}{$1997^{\mathrm{a}}$} \\
\hline Mother and father & 44.4 & 44.3 & 41.0 & 42.5 & 40.3 & 42.8 \\
\hline Mother only & 35.6 & 36.8 & 39.3 & 40.4 & 41.0 & 40.3 \\
\hline Father only & 3.9 & 3.7 & 3.3 & 3.6 & 3.5 & 3.4 \\
\hline Grandparents & 7.7 & 8.0 & 9.3 & 7.6 & 9.8 & 8.6 \\
\hline Ever lived in foster care growing up & $\ldots$ & $\ldots$ & 16.3 & 14.6 & 15.2 & 12.8 \\
\hline \multicolumn{7}{|l|}{ Physical and sexual abuse: } \\
\hline Ever physically abused & 36.1 & 10.4 & 33.8 & 9.6 & 47.6 & 12.8 \\
\hline Ever sexually abused & 32.7 & 5.3 & 34.5 & 4.6 & 39.5 & 5.8 \\
\hline \multicolumn{7}{|l|}{ Parental incarceration: } \\
\hline Mother incarcerated & 3.1 & 1.3 & 4.0 & 1.4 & 8.6 & 4.7 \\
\hline Father incarcerated & 6.3 & 6.4 & 8.2 & 6.3 & 16.8 & 15.9 \\
\hline Mother or father incarcerated & 8.5 & 7.1 & 10.8 & 7.0 & 22.6 & 18.8 \\
\hline
\end{tabular}

Source.-Authors' analyses of the Survey of Inmates in State Correctional Facilities, 1986 (U.S. Department of Justice, Bureau of Justice Statistics 1994), Survey of Inmates in State Correctional Facilities, 1991 (U.S. Department of Justice, Bureau of Justice Statistics 1993), and Survey of Inmates in State and Federal Correctional Facilities, 1997 (U.S. Department of Justice, Bureau of Justice Statistics 2000).

$n=$ sample size (weighted value in parentheses). 
Table 5

Current Offense and Prior Incarceration (\%)

\begin{tabular}{|c|c|c|c|c|c|c|}
\hline & \multicolumn{2}{|c|}{$1986^{a}$} & \multicolumn{2}{|c|}{$1991^{a}$} & \multicolumn{2}{|c|}{$1997^{\mathrm{a}}$} \\
\hline & $\begin{array}{c}\text { Mothers } \\
n=1,967 \\
(13,382)\end{array}$ & $\begin{array}{c}\text { Fathers } \\
n=5,769 \\
(231,856)\end{array}$ & $\begin{array}{c}\text { Mothers } \\
n=1,865 \\
(25,617)\end{array}$ & $\begin{array}{c}\text { Fathers } \\
n=6,179 \\
(373,104)\end{array}$ & $\begin{array}{c}\text { Mothers } \\
n=1,889 \\
(42,963)\end{array}$ & $\begin{array}{c}\text { Fathers } \\
n=6,158 \\
(538,761)\end{array}$ \\
\hline \multicolumn{7}{|l|}{ Current offense: } \\
\hline Violent & 39.1 & 55.2 & 29.0 & 44.8 & 25.7 & 45.4 \\
\hline Property & 42.8 & 29.0 & 30.4 & 23.6 & 28.3 & 21.1 \\
\hline Drug & 12.3 & 9.7 & 33.9 & 23.6 & 34.9 & 23.0 \\
\hline Public order & 4.9 & 5.6 & 5.8 & 7.5 & 10.8 & 10.3 \\
\hline Other & .8 & .6 & .7 & .5 & .3 & .2 \\
\hline Prior incarceration & 39.3 & 57.6 & 43.7 & 57.6 & 53.1 & 67.1 \\
\hline
\end{tabular}

Source.-Authors' analyses of the Survey of Inmates in State Correctional Facilities, 1986 (U.S. Department of Justice, Bureau of Justice Statistics 1994), Survey of Inmates in State Correctional Facilities, 1991 (U.S. Department of Justice, Bureau of Justice Statistics 1993), and Survey of Inmates in State and Federal Correctional Facilities, 1997 (U.S. Department of Justice, Bureau of Justice Statistics 2000).

${ }^{\text {a }} n=$ sample size (weighted value in parentheses).

abuse also increased for both mothers and fathers. Overall, reported physical or sexual abuse histories are much more prevalent among mothers, though part of this discrepancy may reflect underreporting by fathers. Nonetheless, it is noteworthy that reported rates of abuse increased for both men and women between 1986 and 1997.

Considerably more parents in state prison reported a history of their parents having been incarcerated in 1997 than in 1986. Only 3.1 percent of mothers incarcerated in state prisons during 1986 reported having a mother incarcerated, compared with 8.6 percent of mothers in state prisons in 1997. The same pattern exists for fathers: 1.3 percent of fathers incarcerated during 1986 and 4.7 percent of those incarcerated during 1997 reported having a mother who was incarcerated. The figures for paternal incarceration are also substantially higher for 1997 than for 1991 and 1986. When we consider the share of parents who had either parent incarcerated, we find an especially sharp increase from 1986 to 1997: 8.5 percent of mothers and 7.1 percent of fathers in 1986 had either a mother or father incarcerated, compared with 22.6 percent of mothers and 18.8 percent of fathers in 1997.

\section{Drug Involvement and Current Offense}

In 1997, about 35 percent of mothers and 23 percent of fathers in state prison were incarcerated for drug-related crimes, compared with a mere 12.3 percent of mothers and 9.7 percent of fathers in 1986 (table 5). For both mothers and fathers, this shift occurred primarily between 1986 and 1991, when 33.9 percent of mothers and 23.6 percent of fathers in state prison were incarcerated for drug-related offenses. Across years, 
Table 6

Parents' Drug Use (\%)

\begin{tabular}{|c|c|c|c|c|c|c|}
\hline & \multicolumn{2}{|c|}{$1986^{\mathrm{a}}$} & \multicolumn{2}{|c|}{$1991^{\mathrm{a}}$} & \multicolumn{2}{|c|}{$1997^{\mathrm{a}}$} \\
\hline & $\begin{array}{c}\text { Mothers } \\
n=1,967 \\
(13,382)\end{array}$ & $\begin{array}{c}\text { Fathers } \\
n=5,769 \\
(231,856)\end{array}$ & $\begin{array}{c}\text { Mothers } \\
n=1,865 \\
(25,617)\end{array}$ & $\begin{array}{c}\text { Fathers } \\
n=6,179 \\
(373,104)\end{array}$ & $\begin{array}{c}\text { Mothers } \\
n=1,889 \\
(42,963)\end{array}$ & $\begin{array}{c}\text { Fathers } \\
n=6,158 \\
(538,761)\end{array}$ \\
\hline \multicolumn{7}{|l|}{ Marijuana/hashish:" } \\
\hline Ever used & 62 & 77 & 66 & 76 & 69 & 80 \\
\hline Ever used regularly & 39 & 54 & 40 & 54 & 68 & 77 \\
\hline \multicolumn{7}{|l|}{ Cocaine/crack: ${ }^{c}$} \\
\hline Ever used & 50 & 46 & 63 & 52 & 67 & 52 \\
\hline Ever used regularly & 26 & 24 & 45 & 34 & 54 & 36 \\
\hline \multicolumn{7}{|l|}{ Heroin/opiates: } \\
\hline Ever used & 35 & 29 & 32 & 27 & 31 & 25 \\
\hline Ever used regularly & 28 & 21 & 22 & 15 & 22 & 15 \\
\hline
\end{tabular}

Source. - Authors' analyses of the Survey of Inmates in State Correctional Facilities, 1986 (U.S. Department of Justice, Bureau of Justice Statistics 1994), Survey of Inmates in State Correctional Facilities, 1991 (U.S. Department of Justice, Bureau of Justice Statistics 1993), and Survey of Inmates in State and Federal Correctional Facilities, 1997 (U.S. Department of Justice, Bureau of Justice Statistics 2000).

${ }^{\text {a }} n=$ sample size (weighted value in parentheses).

${ }^{\mathrm{b}}$ The 1986 respondents are asked about marijuana only, which may or may not have included hashish.

${ }^{c}$ The 1986 respondents are asked about cocaine only, which may or may not have included crack.

the most common reason for fathers' incarceration was a violent offense. For mothers, however, the most common offense involved violence in 1986 and drugs in both 1991 and 1997. The proportion of parents who reported at least one period of incarceration prior to this incarceration rose steadily between 1986 and 1997: 39.3 percent of 1986 mothers and 57.6 percent of 1986 fathers reported being previously incarcerated, compared with 53.1 percent of 1997 mothers and 67.1 percent of 1997 fathers.

Regular crack-cocaine use or other cocaine use also increased substantially between 1986 and 1997 among state prison inmates (table 6). In 1986, 26 percent of mothers and 24 percent of fathers reported ever having used crack regularly, compared with 54 percent of mothers and 36 percent of fathers in 1997 . The proportion of inmates who reported ever having used heroin or other opiates decreased between 1986 and 1997. Histories of experimental and regular use of marijuana or hash increased slightly across these years.

\section{Children's Living Arrangements and Correspondence with Parents}

Table 7 displays living arrangements of children whose parents were incarcerated in state prison during 1986, 1991, and 1997. The most common arrangement for children with mothers in prison is with a grandparent, while the most common arrangement for children with a father in prison is with a mother or stepmother. For instance, nearly 
Table 7

Children's Living Arrangements (\%)

$1986^{\mathrm{a}}$

$1991^{\mathrm{a}}$

\begin{tabular}{|c|c|c|c|c|c|c|}
\hline & \multicolumn{2}{|c|}{$1986^{\mathrm{a}}$} & \multicolumn{2}{|c|}{$1991^{\mathrm{a}}$} & \multicolumn{2}{|c|}{$1997^{\mathrm{a}}$} \\
\hline & $\begin{array}{c}\text { Children of Mothers } \\
n=4,850 \\
(33,075)\end{array}$ & $\begin{array}{c}\text { Children of Fathers } \\
n=12,741 \\
(512,382)\end{array}$ & $\begin{array}{c}\text { Children of Mothers } \\
n=4,772 \\
(65,691)\end{array}$ & $\begin{array}{l}\text { Children of Fathers } \\
n=15,117 \\
(911,565)\end{array}$ & $\begin{array}{c}\text { Children of Mothers } \\
n=4,446 \\
(102,132)\end{array}$ & $\begin{array}{c}\text { Children of Fathers } \\
n=12,551 \\
(1,097,139)\end{array}$ \\
\hline Parent & 20.0 & 85.0 & 21.5 & 84.5 & 21.5 & 82.2 \\
\hline Grandparent & 42.2 & 8.1 & 41.2 & 7.3 & 44.7 & 9.0 \\
\hline Other relative & 21.0 & 2.4 & 18.0 & 2.3 & 18.7 & 3.0 \\
\hline $\begin{array}{l}\text { Foster care, } \\
\text { agency or } \\
\text { institution }\end{array}$ & 10.7 & 1.8 & 9.1 & 1.8 & 7.9 & 1.3 \\
\hline Friends & 2.5 & .3 & 3.2 & .3 & 1.8 & .3 \\
\hline Alone & .4 & .3 & 1.8 & 1.0 & 2.0 & 1.4 \\
\hline $\begin{array}{l}\text { Someone else } \\
\text { or other }\end{array}$ & 2.5 & .6 & 3.2 & 1.8 & 2.3 & .9 \\
\hline
\end{tabular}

SourCE.-Authors' analyses of the Survey of Inmates in State Correctional Facilities, 1986 (U.S. Department of Justice, Bureau of Justice Statistics 1994), Survey of Inmates in State Correctional Facilities, 1991 (U.S. Department of Justice, Bureau of Justice Statistics 1993), and Survey of Inmates in State and Federal Correctional Facilities, 1997 (U.S. Department of Justice, Bureau of Justice Statistics 2000).

NoTE. - Data on children's living arrangements in the surveys are reported at the level of the family, not the child. If a family reported more than one living arrangement for the children, we divided the children equally among living arrangements to arrive at a count of children by living arrangement. Totals do not sum to exactly $100 \%$ owing to rounding and to missing data. Response categories vary slightly by year (e.g., stepparents are included with other relatives in 1986 but with parents in 1991 and 1997).

a $n=$ sample size (weighted value in parentheses). 
Table 8

Parent's Correspondence with Children, 1991 and 1997 (\%)

\begin{tabular}{|c|c|c|c|c|}
\hline & \multicolumn{2}{|c|}{$1991^{\mathrm{a}}$} & \multicolumn{2}{|c|}{$1997^{\mathrm{a}}$} \\
\hline & $\begin{array}{c}\text { Mothers } \\
n=1,865 \\
(25,617)\end{array}$ & $\begin{array}{c}\text { Fathers } \\
n=6,179 \\
(373,104)\end{array}$ & $\begin{array}{c}\text { Mothers } \\
n=1,889 \\
(42,963)\end{array}$ & $\begin{array}{c}\text { Fathers } \\
n=6,158 \\
(538,761)\end{array}$ \\
\hline \multicolumn{5}{|l|}{ Makes or receives phone calls: } \\
\hline Daily or almost daily & 16.3 & 8.2 & 11.3 & 6.2 \\
\hline At least once a week & 29.5 & 22.3 & 26.5 & 19.2 \\
\hline At least once a month & 16.9 & 16.9 & 15.1 & 16.3 \\
\hline Less than once a month & 8.8 & 12.4 & 13.0 & 13.9 \\
\hline Never & 28.0 & 39.8 & 32.7 & 41.8 \\
\hline \multicolumn{5}{|l|}{ Sends or receives mail: } \\
\hline Daily or almost daily & 8.8 & 6.9 & 9.5 & 4.4 \\
\hline At least once a week & 36.1 & 24.0 & 35.4 & 22.2 \\
\hline At least once a month & 22.3 & 21.9 & 20.1 & 22.8 \\
\hline Less than once a month & 10.9 & 15.3 & 12.4 & 16.9 \\
\hline Never & 21.0 & 31.4 & 21.0 & 31.2 \\
\hline \multicolumn{5}{|l|}{ Receives personal visits: } \\
\hline Daily or almost daily & .4 & 1.0 & 1.0 & .7 \\
\hline At least once a week & 8.6 & 7.4 & 7.8 & 6.4 \\
\hline At least once a month & 17.9 & 14.8 & 14.3 & 13.2 \\
\hline Less than once a month & 20.6 & 21.6 & 18.6 & 18.1 \\
\hline Never & 51.8 & 54.6 & 53.9 & 56.0 \\
\hline
\end{tabular}

Source.-Authors' analyses of the Survey of Inmates in State Correctional Facilities, 1986 (U.S. Department of Justice, Bureau of Justice Statistics 1994), Survey of Inmates in State Correctional Facilities, 1991 (U.S. Department of Justice, Bureau of Justice Statistics 1993), and Survey of Inmates in State and Federal Correctional Facilities, 1997 (U.S. Department of Justice, Bureau of Justice Statistics 2000). Questions regarding correspondence with children were added in 1991.

${ }^{\mathrm{a}} n=$ sample size (weighted value in parentheses).

two-thirds (63.4 percent) of children with mothers in state prison were in the care of a grandparent or other relative in 1997, compared with only 12 percent of children with fathers in state prison during this year. This pattern was consistent across years. The proportion of incarcerated fathers' children who lived with a parent was consistent from 1986 to 1991 (85 percent and 84.5 percent, respectively), though slightly lower for 1997 (82.2 percent).

Correspondence variables are available only in the 1991 and 1997 surveys, so we are unable to determine how correspondence changed over the entire 11-year period. Data suggest, however, that the frequency of all forms of correspondence between parents in state prison and their children declined from 1991 to 1997 (see table 8). For instance, the proportion of mothers who reported monthly visits with children fell from 17.9 percent in 1991 to 14.3 percent in 1997. Similarly, the share of fathers who reported monthly personal visits declined from 14.8 percent in 1991 to 13.2 percent in 1997. More than half of parents reported 
no personal visits with children, and more than one-third reported no phone correspondence with children.

Children of State and Federal Inmates as a Growing Share of Children Living in Foster Care and with Grandparents

Here we look at the overall population of children of both state and federal inmates and analyze what share these children make up of children living in foster care and of children living with grandparents. We find that children with incarcerated parents became an increasingly large share of the total U.S. nonrelative foster care population between 1986 and 1997 (which includes children living in foster care, an agency, or an institution). About 229,600 U.S. children were in out-of-home care with nonrelatives in 1986, compared with 337,000 in $1997 .{ }^{3}$ The share of U.S. children in nonrelative foster care with an incarcerated parent increased from 5.7 percent in 1986 to 7.1 percent in 1997, an increase of 25 percent over the level in $1986 .{ }^{4}$ This figure peaked in 1991, with children of incarcerated parents constituting 8.5 percent of the U.S. foster care population for that year. Thus, children with incarcerated parents became an increasingly large share of the foster care population between 1986 and 1997 (see appendix).

Although the overall number of children of incarcerated parents living in foster care increased from 1986 to 1997, the proportion of mothers' children living in out-of-home care (i.e., foster care, agency, or an institution) declined from 10.7 percent in 1986 to 7.9 percent in 1997. Over the same time period, proportionately more parents report children living with a grandparent. This suggests that grandparents are caring for some of the children who previously would have been in foster care, which makes sense given the increase over this period in kinship care. Survey response categories make it impossible to discern whether these kinship arrangements are formal (i.e., grandparent subject to state regulations in exchange for foster care maintenance payments) or more informal arrangements. Nonetheless, it is clear from our data that children with incarcerated parents are becoming an increasingly large share of U.S. children living with a grandparent. Based on figures on the total number of U.S. children living with grandparents (U.S. Census Bureau 2001), we estimate that children with an incarcerated parent made up 5.8 percent of U.S. children who lived with a grandparent caregiver without a parent present in 1986, 10.7 percent of this population in 1991, and 11.8 percent of this population in 1997 (see appendix).

\section{Discussion}

Although it is well known that the U.S. prison population has grown dramatically over the last 2 decades, it is less clear how the population 
of parents in prison has grown and changed. Our work examines this growth over an 11-year period using three large, nationally representative surveys of inmates in state correctional facilities (we also conduct some analyses of inmates in both state and federal facilities using data from the 1997 survey, which included both populations). We find that state and federal inmates were parents to over 1.3 million children in 1997, a near tripling of the 1986 figure.

In our more detailed analyses of state prisoners, one of the most surprising demographic changes we observe is that fewer parents (both mothers and fathers) had custody of fewer children prior to their incarceration in 1997 than in 1986. We also find that, by several measures, parents incarcerated in state prisons during 1997 were a much more troubled population than parents incarcerated during 1986. More of the 1997 parents reported histories of physical or sexual abuse, prior sentences to incarceration, incarceration of their own parents, and regular drug use. One interesting exception is that a larger share of 1997 parents completed high school or earned a GED prior to entering prison than did 1986 parents. Rates of high school and GED completion were highest in 1991, and the prevalence of a history of abuse was lowest for both mothers and fathers during 1991. These findings perhaps indicate that changes in drug policy initially caught a broader spectrum of people.

Paralleling the latter part of the crack-cocaine epidemic and the shift in national drug control policy, the proportion of parents (especially mothers) who were incarcerated in state prisons for drug-related offenses increased dramatically between 1986 and 1991. A notable growth in the number of parents who regularly used crack cocaine and the number of parents who reported prior sentences to incarceration also occurred during this period. Taken together, these findings may help to explain why fewer parents had custody of fewer children in 1997 than in 1986. Parents may have already lost custody of their children for drugor incarceration-related reasons prior to this incarceration.

When we consider the overall population of children of parents incarcerated in state or federal prison, results indicate that children with incarcerated parents became an increasingly large share of the foster care population between 1986 and 1997. The proportion of U.S. children in nonrelative foster care who had an incarcerated parent increased by about 25 percent during this period. The largest increase occurred between 1986 and 1991, with 5.7 percent of foster care children having a parent in prison in 1986 and 8.5 percent in 1991. Although this figure declined slightly to 7.1 percent in 1997 , it is nevertheless concerning that an increasing number of children of incarcerated parents are in the foster care system.

Data also indicate that inmates' own parents are assuming a considerable amount of care for this population of children, especially for children whose mothers are in prison. Children with a parent incar- 
cerated in state or federal prison made up about 12 percent of the population of U.S. children living with a grandparent in 1997, compared with only 5.8 percent in 1986. Data from the National Survey of Households and Families indicates that more than half of grandparents raising their grandchildren do so for 3 or more years and that about one-quarter live below the poverty level (Fuller-Thomson, Minkler, and Driver 1997). The fact that many grandparents are raising young grandchildren for several years on a limited budget, coupled with the more general stress of familial incarceration, suggests that policy makers and service providers should give more thought to financial and supportive services for this population. Our analysis also suggests that some children who formerly would have been placed in foster care are now living with grandparents instead. It is important to determine what types of families these children come from and whether they face the same risk factors as children in foster care (Johnson and Waldfogel 2002).

Though concerns about visitation have been widely articulated, there remains considerable variability in how child welfare agencies and prison facilities deal with incarcerated parents and their families. The Bureau of Prisons "encourages visiting by family, friends, and community groups," yet visitation regulations require only that facilities provide at least 4 hours of visiting per month (U.S. Department of Justice, Federal Bureau of Prisons 1999). Child welfare agencies also have discretion in the extent to which they provide services to incarcerated parents. California and New York are examples of two states that have set special standards for the nature of "reasonable efforts" in the case of incarcerated parents (Genty 1998), such as arranging visits and providing transportation. Though encouraging, we know little about whether states' efforts have actually improved correspondence between inmates and their children.

In fact, our data suggest that correspondence between state inmates and their children actually declined from 1991 and 1997. Given the potential importance of parent-child correspondence for child well-being and criminal justice outcomes (Koban 1983; Hairston 1991; Boudouris 1996; Wooldredge 1999), future research should examine factors that promote or impede parent-child contact during imprisonment. It would be helpful for practitioners and policy makers if researchers could tease apart the individual (e.g., demographic and social characteristics of parents, caregivers, and children) and institutional constraints (e.g., prison facilities, child welfare services) on correspondence.

Given that most children of incarcerated parents are not under state care, it is important that more systematic reporting occur at the level of prison facilities and child welfare agencies. The Child Welfare League of America publicized the seriousness of the problem in its 1998 survey of state agencies and in the special issue of Child Welfare on parental incarceration. The survey was conducted in 1997; it would be useful if 
funding were provided to update this survey. Have efforts of child welfare agencies to address the needs of children of incarcerated parents been improved? Improved reporting of programs and policies regarding incarcerated parents would help us to determine whether states' efforts to improve visitation have been successful.

Social science research can also make important contributions by conducting additional studies on the consequences of parental incarceration for children. Such studies should look at the incarceration of fathers as well as mothers. As one anonymous reviewer pointed out, much of the literature focuses on mothers and thus may underestimate the impact of parental incarceration on families and communities. Denise Johnston (2001) notes that much of the existing research on this topic has been hampered by conceptual and methodological issues such as a focus on the isolated offender, difficulty identifying representative samples, data accuracy, and assumptions about inmates and their families. By more carefully identifying the consequences of the problem for children and families, we can begin to explore child risk and protective factors.

Although our analysis represents an important attempt to present a picture of the problem over time using large, nationally representative survey data, several limitations are noteworthy. First, it should be noted that our analyses are limited to children of parents in prison and do not include parents who are involved in the criminal justice system in other ways (e.g., in jail or on probation) or who have been incarcerated or involved with criminal justice in the past. Thus, we do not consider the full extent of involvement of children's parents with the criminal justice system. Second, our analyses do not take into account the length of time that parents are in prison, which has increased over the period we study (Ditton and Wilson 1999; Sabol and McGready 1999; Hughes Wilson, and Beck 2001), meaning that children are separated from their parents for longer periods of time. For all incarcerated parents, this may influence their ability to care for their children. For incarcerated parents whose children are not in the care of a relative, this may have important consequences for maintaining parental rights. A third concern is that we may have slightly overcounted the number of children with incarcerated parents if some children have two parents in prison. Because we know of no national estimates on the number of children with two incarcerated parents, we were unable to adjust our figures downward. A related issue is that we used rough estimates of the number of children in nonrelative foster care. Fourth, even though we use estimates on federal prisoners to get at the magnitude of the problem, our substantive analyses were limited to state prisoners. As an anonymous reviewer pointed out, state and federal inmates may differ in several important ways. Thus, our results should not be generalized to all inmates. Fifth, response categories used in the survey may have con- 
strained our estimates, a problem often encountered with secondary analyses. For example, response categories do not distinguish between children who are living with relatives and those who are in formal kinship care arrangements. In assessing the impact of parental incarceration on the child welfare system (as well as on grandparents), this is an important distinction. A related concern is that survey data do not distinguish between children who were already in foster care prior to their parent's incarceration and those who were placed in the child welfare system as a consequence of the parent's incarceration. Nonetheless, our figures suggest that a share of U.S. children in the foster care population may be affected by incarceration at a point in time and thus may have special casework needs.

Despite these limitations, this article contributes to our understanding of how the problem of parental incarceration has grown and changed over time and confirms earlier work that suggests that children of incarcerated parents may be an especially vulnerable population. The implications of parental incarceration are far reaching. Not only does incarceration itself cost an enormous amount of money each year, but it also has important effects on children, families, and the child welfare system. Parental incarceration may also have longer-run detrimental effects for children and families that threaten to incur additional costs to society (e.g., recidivism, intergenerational crime, and incarceration). The seriousness of the problem, especially for children, is recognized in the 2001 Amendments of the Safe and Stable Families Act (H.R. 28732 ), which allocates $\$ 67$ million to mentoring programs for children with incarcerated parents.

In summary, children of incarcerated parents are a group that faces special risks and that is increasing in size. In the absence of a coordinated policy and service response on the part of criminal justice and child welfare agencies, these children may be at risk for a number of emotional, behavioral, and academic difficulties, and their parents may be at risk for termination of parental rights and recidivism. With children of incarcerated parents now making up at least 7 percent of foster children and 12 percent of children living with grandparents, it is time to develop such a response. 


\section{Appendix}

Table A1

Data on Children of Incarcerated Parents Living in Foster Care or with Relatives

\begin{tabular}{|c|c|c|c|}
\hline & 1986 & 1991 & 1997 \\
\hline $\begin{array}{l}\text { Number of minor children with parents } \\
\text { in state prison }\end{array}$ & 545,457 & 977,256 & $1,199,271$ \\
\hline $\begin{array}{l}\text { Number of minor children with parents } \\
\text { in federal prison }\end{array}$ & 59,591 & 84,200 & 121,977 \\
\hline $\begin{array}{l}\text { Number of minor children with parents } \\
\text { in state or federal prison }\end{array}$ & 605,048 & $1,061,456$ & $1,321,248$ \\
\hline Number of minor U.S. children ${ }^{a}$ & $62,866,000$ & $65,110,905$ & $69,603,989$ \\
\hline $\begin{array}{l}\text { Proportion of U.S. children with parent } \\
\text { in prison }\end{array}$ & $10 / 1,000$ & $16 / 1,000$ & $19 / 1,000$ \\
\hline $\begin{array}{l}\text { Number of U.S. children living with a } \\
\text { grandparent without parent(s) present }{ }^{\mathrm{a}}\end{array}$ & $\begin{array}{c}956,000 \\
\text { (1985 imputed) }\end{array}$ & $\begin{array}{c}935,000 \\
(1990)\end{array}$ & $1,309,000$ \\
\hline $\begin{array}{l}\text { Number of inmates' children living with a } \\
\text { grandparent }\end{array}$ & 55,735 & 100,776 & 155,049 \\
\hline $\begin{array}{l}\text { Proportion of U.S. children who live with } \\
\text { a grandparent and have an incarcer- } \\
\text { ated parent }(\%)\end{array}$ & 5.8 & 10.7 & 11.8 \\
\hline $\begin{array}{l}\text { Number of inmates' children in foster } \\
\text { care, an agency, or an institution }\end{array}$ & 13,156 & 24,276 & 23,990 \\
\hline Total U.S. foster care population ${ }^{\mathrm{b}}$ & 280,000 & 414,000 & 537,000 \\
\hline Proportion in relative foster care $^{c}$ & $18 \%$ & $31 \%$ & $\begin{array}{l}200,000 \\
\text { children }\end{array}$ \\
\hline $\begin{array}{l}\text { Estimated number of U.S. children in } \\
\text { nonrelative foster care }\end{array}$ & 229,000 & 285,660 & 337,000 \\
\hline $\begin{array}{l}\text { Proportion of foster care population with } \\
\text { a parent in prison }(\%)\end{array}$ & 5.7 & 8.5 & 7.1 \\
\hline
\end{tabular}

${ }^{\text {a }}$ See http://www.census.gov/statab.

${ }^{\mathrm{b}}$ See U.S. House of Representatives 2000.

c The 1986 and 1991 figures are from U.S. House of Representatives (2000); the 1997 figure is from Waters Boots and Geen (1999).

\section{References}

Baunach, Phyllis J. 1985. Mothers in Prison. New Brunswick, N.J.: Transaction Books.

$\rightarrow$ Beckerman, Adela. 1989. "Incarcerated Mothers and Their Children in Foster Care: The Dilemma of Visitation." Children and Youth Services Review 11:175-83.

- 1991. "Women in Prison: The Conflict between Confinement and Parental Rights." Social Justice 18 (3): 171-83.

- 1994. "Mothers in Prison: Meeting the Prerequisite Conditions for Permanency Planning." Social Work 39 (1): 9-14.

. 1998. "Charting a Course: Meeting the Challenge of Permanency Planning for Children of Incarcerated Mothers." Child Welfare 77 (5): 513-29.

Bloom, Barbara, and David Steinhart. 1993. Why Punish the Children? A Reappraisal of the Children of Incarcerated Mothers in America. San Francisco: National Council on Crime and Delinquency. 
Boudouris, James. 1996. Parents in Prison: Addressing the Needs of Families. Lanham, Md.: American Correctional Association.

Child Welfare League of America. 1998. State Agency Survey on Children with Incarcerated Parents. Washington, D.C.: Child Welfare League of America.

Ditton, Paula M., and Doris James Wilson. 1999. Truth in Sentencing in State Prisons. NCJ 170032. Washington, D.C.: U.S. Department of Justice, Bureau of Justice Statistics.

Fuller-Thomson, Esme, Meredith Minkler, and Diane Driver. 1997. "A Profile of Grandparents Raising Grandchildren in the United States." Gerontologist 37:406-11.

Genty, Philip M. 1995. "Termination of Parental Rights among Prisoners: A National Perspective." Pp. 167-82 in Children of Incarcerated Parents, edited by Katherine Gabel and Denise Johnston. New York: Lexington Books.

— 1998. "Permanency Planning in the Context of Parental Incarceration: Legal Issues and Recommendations." Child Welfare 77:543-59.

Greenfeld, Lawrence A., and Tracy L. Snell. 1999. Women Offenders. NCJ 175688. Washington, D.C.: U.S. Department of Justice, Bureau of Justice Statistics.

Hairston, Creasie F. 1991. "Family Ties during Imprisonment: Important to Whom and for What?" Journal of Sociology and Social Welfare 18:87-104.

Hughes, Timothy A., Doris James Wilson, and Allen J. Beck. 2001. Trends in State Parole, 1990-2000. NCJ 184735. Washington, D.C.: U.S. Department of Justice, Bureau of Justice Statistics.

Johnson, Elizabeth I., and Jane Waldfogel. 2002. "Children of Incarcerated Parents: Where Are They Living and What Risks Do They Face?” Manuscript. University of Michigan and Columbia University.

Johnston, Denise. 1991. Jailed Mothers. Pasadena, Calif.: Pacific Oaks Center for Children of Incarcerated Parents.

-1992. Children of Offenders. Pasadena, Calif.: Pacific Oaks Center for Children of Incarcerated Parents.

— 1993. Caregivers of Prisoners' Children. Pasadena, Calif.: Center for Children of Incarcerated Parents.

- 1995. "Effects of Parental Incarceration." Pp. 59-88 in Children of Incarcerated Parents, edited by Katherine Gabel and Denise Johnston. New York: Lexington Books.

- 2001. "Incarceration of Women and Effects on Parenting." Paper presented at the Conferences on the Effects of Incarceration for Children and Families, Northwestern University, Institute for Policy Research, Chicago, May.

Kampfner, Christina J. 1995. "Post-traumatic Stress Reactions in Children of Imprisoned Mothers." Pp. 89-100 in Children of Incarcerated Parents, edited by Katherine Gabel and Denise Johnston. New York: Lexington Books.

Koban, Linda Abram. 1983. "Parents in Prison: A Comparative Analysis of the Effects of Incarceration on the Families of Men and Women." Research in Law, Deviance, and Social Control 5:171-83.

McGowan, Brenda, and Karen Blumenthal. 1978. Why Punish the Children? Hackensack, N.J.: National Council on Crime and Delinquency.

Mumola, Christopher J. 2000. Incarcerated Parents and Their Children. NCJ 182335. Washington, D.C.: U.S. Department of Justice, Bureau of Justice Statistics.

National Conference of State Legislatures. 2001. "Summaries of State Legislation Enacted in Response to the Adoption and Safe Families Act." Searchable on-line database available at http://www.ncsl.org/statefed/cf/asfasearch.htm (accessed on April 5, 2002).

Sabol, William J., and John McGready. 1999. Time Served in Prison by Federal Offenders, 1986-1997. NCJ 171682. Washington, D.C.: U.S. Department of Justice, Bureau of Justice Statistics.

$\rightarrow$ Schafer, N. E., and A. B. Dellinger. 1999. "Jailed Parents: An Assessment." Women and Criminal Justice 10 (4): 73-91.

Smith, Barbara E., and Sharon Goretsky Elstein. 1994. Children on Hold: Improving the Response to Children Whose Parents Are Arrested and Incarcerated. Washington, D.C.: American Bar Association, Center for Children and the Law.

Stanton, Ann. 1980. When Mothers Go to Jail. Lexington, Mass.: Lexington Books.

U.S. Census Bureau. 2001. Statistical Abstract of the United States, 2000. Washington, D.C.: U.S. Census Bureau. 
U.S. Department of Justice. 1989. Correctional Population in the United States, 1986. Washington, D.C.: Bureau of Justice Statistics.

- 1993a. Correctional Population in the United States, 1991. Washington, D.C.: Bureau of Justice Statistics.

. 1993b. Survey of State Prison Inmates, 1991. NCJ 136949. Washington, D.C.: U.S. Department of Justice, Bureau of Justice Statistics.

U.S. Department of Justice, Bureau of Justice Statistics. 1993. Survey of Inmates in State Correctional Facilities, 1991. Computer file. Conducted by U.S. Department of Commerce, Bureau of the Census. ICPSR ed. Ann Arbor, Mich.: Inter-university Consortium for Political and Social Research (producer and distributor).

- 1994. Survey of Inmates in State Correctional Facilities, 1986. Computer file. Conducted by the U.S. Department of Commerce, Bureau of the Census. 2d ICPSR ed. Ann Arbor, Mich.: Inter-university Consortium for Political and Social Research (producer and distributor).

- 2000. Survey of Inmates in State and Federal Correctional Facilities, 1997. Computer file. Complied by the U.S. Department of Commerce, Bureau of the Census. ICPSR ed. Ann Arbor, Mich.: Inter-university Consortium for Political and Social Research (producer and distributor).

U.S. Department of Justice, Federal Bureau of Prisons. 1999. "Visiting Regulations." P.S. 5267.06. Available on-line at http://www.bop.gov (accessed May 1, 2002).

U.S. House of Representatives. 2000. Overview of Entitlement Programs: 2000 Green Book. Background Material and Data on Programs within the Jurisdiction of the Committee on Ways and Means. Washington, D.C.: U.S. Government Printing Office.

Waters Boots, Shelley, and Rob Geen. 1999. Family Care or Foster Care? How State Policies Affect Kinship Caregivers. Washington, D.C.: Urban Institute.

$\rightarrow$ Wooldredge, John D. 1999. "Inmate Experiences and Psychological Well-Being." Criminal Justice and Behavior 26 (2): 235-50.

Zietz, Dorothy. 1963. "Child Welfare Services in a Women's Correctional Facility." Child Welfare 42:185-90.

\section{Notes}

1. It is possible that a child may have two incarcerated parents, which would result in double counting of children. However, because reliable estimates on the number of children who have two incarcerated parents are not available, we are unable to adjust the figures.

2. Data not available for 1986 .

3. We calculate the number of children in out-of-home care with nonrelatives by taking the total number of children in out-of-home care for each year and subtracting the number estimated to be in kinship foster care with a relative (using data from U.S. House of Representatives' Overview of Entitlement Programs, or Green Book [U.S. House of Representatives 2000]). See appendix for details.

4. Our estimates of the proportion of U.S. children living in foster care, an agency, or an institution include children with parents in state and federal prison. Since the inmates in federal prisons were included in the survey in 1997 only, we use the data on the living arrangements of their children in 1997 to impute the living arrangements of children of federal inmates in the two earlier years. 